\title{
AS FORMAS ATUAIS DAS LUTAS DE CLASSES E A QUESTÃO DO MEDIADOR UNIVERSALIZANTE
}

\author{
Marcelo Braz \\ Universidade Federal do Rio de Janeiro (UFRJ) \\ Escola Nacional Florestan Fernandes (ENFF)
}

\begin{abstract}
AS FORMAS ATUAIS DAS LUTAS DE CLASSES E A QUESTÃO DO MEDIADOR UNIVERSALIZANTE
Resumo: Artigo resultante de reflexões sistematizadas no "Debate com Convidados" durante a VI Jornada Internacional de Políticas Públicas, em agosto de 2013, em São Luís- Maranhão. Seu propósito é examinar as manifestações que explodiram, como se tivessem caído de um "céu sem nuvens", em junho de 2013, para rediscutir a relação entre as lutas sociais e a questão do mediador universalizante tratado como mediador universal histórico-concreto. Finalmente retoma o que se chama no texto de sentido histórico das lutas de classes nas obras de Marx e de Engels.

Palavras-chave: Lutas sociais, mediador universalizante, história.
\end{abstract}

THE CURRENT FORMS OF CLASS STRUGGLES AND THE QUESTION OF UNIVERSALIZING MEDIATOR

Abstract: Article resulting from systematic reflections on the "Discussion with Guests" at the VI International Journey of Public Policies in August 2013 in São Luís, Maranhão. Its purpose is to examine the demonstrations that erupted, as if they had fallen from a "cloudless sky", in June 2013, to revisit the relationship between social struggles and the question of universalizing mediator treated as universal historical-concrete mediator. Finally incorporates what is called in the text of historical sense of class struggles in the works of Marx and Engels.

Keywords: Social struggles, universalizing mediator, history. 


\section{INTRODUÇÃO}

As ricas interpretações da realidade realizadas na VI Jornada Internacional de Políticas Públicas (em agosto de 2013, na ilha de São Luís do Maranhão) foram precisas na identificação do significado da crise atual, na explicitação de suas consequências nos processos de produção e de reprodução do capital e na evidenciação das contradições capitalistas, abrindo caminhos para discutirmos o cenário através do qual se desenvolvem os movimentos e lutas sociais contemporâneos. Basta lembrar a correta análise do mestre François Chesnais que, na Conferência de Abertura do evento, mostrounos dados sociais e econômicos que o levaram a afirmar que a crise atual do capitalismo é uma crise insuperável. Ou, também, a instigante análise do equatoriano Napoleón Saltos para quem esta mesma crise se apresenta no século XXI como uma crise estrutural civilizatória. Recordemos, ainda, da contribuição do economista Paulo Nakatani que talvez inspirado em Lênin para quem a política é a economia concentrada - foi certeiro ao afirmar que não se pode dissociar a análise da economia da análise da política.

Mas não me parece casual que houve um grande ausente nas análises feitas na jornada: o partido político. Tal ausência não se deve à incapacidade ou à insuficiência de um ou outro analista, mas às imensas dificuldades, postas pelo capitalismo contemporâneo, de pensá-lo como instrumento de universalização das lutas sociais. Trata-se de um tema muito caro à tradição marxista cujo maior desafio consiste na atualização das ideias clássicas sobre o tema, fundamentalmente as que foram elaboradas por Marx, Engels, Lenin, Rosa Luxemburgo, Trotsky, Lukács e Gramsci.

Gostemos ou não de Lênin - e estou convencido, assim como sempre gosta de nos alertar o professor Ronaldo do Livramento Coutinho, que o revolucionário russo é, de longe, o marxista mais exilado da academia, ademais de pouco ou mal lido fora dela -ele tem muito a nos dizer sobre o problema em questão.

Para entender as lutas de classes (ou, mais precisamente, para diferenciar suas formas concretas e históricas), Lenin faz uma distinção fundamental entre forças motrizes e forças dirigentes que desenvolve a partir da distinção, presente na obra Que Fazer?, entre luta econômica e luta política. As forças motrizes abrangem o conjunto das lutas sociais que, de modo mais ou menos espontâneo, desenvolvem-se entre os diversos segmentos do proletariado. Elas podem ter um efeito passageiro, de duração transitória, à medida que as demandas que as mobilizaram são atendidas ou se dissolvem, seja pela ausência de direção política, seja pela repressão das classes dominantes. Mas elas guardam em si o potencial para evoluírem até formas que transcendem seus interesses imediatos, evolução que não depende delas, pois que pressupõe a ação de forças que consigam atuar para vinculá-las aos interesses mais gerais que as envolvem: as forças dirigentes. Estas são justamente as que reúnem as condições para alçar as lutas particulares e imediatas a um patamar superior de luta e de consciência social. As primeiras atuam no limite das lutas econômicas parciais. As segundas agem para articular essas demandas sociais particulares às universais, vinculando-as aos interesses comuns de classe.

Tal distinção me parece extremamente útil para pensar, por exemplo, as manifestações que explodiram, como se tivessem caído de um céu sem nuvens, em junho de 2013. As jornadas de lutas que se iniciaram em junho trouxeram uma qualidade nova - justamente o despertar de forças motrizes que pareciam adormecidas - às lutas de classes no Brasil, criando condições subjetivas para romper um ciclo histórico de amortecimento produzido pelos últimos dez anos de apassivamento operado pelos governos petistas. No entanto, se uma fagulha pode incendiar uma pradaria (para lembrar célebre frase de Mao Tsé-Tung), não se pode esquecer que a fagulha (que no caso das jornadas de junho foi o aumento das passagens de ônibus) é apenas o detonador de um conjunto de contradições que vinham se desenvolvendo. Se não se compreendem essas contradições e se não se relaciona a fagulha a elas, nada teremos para além de incêndios mais ou menos isolados. Também nada poderemos fazer diante de um cenário incendiário se não formos capazes de dirigir a situação no sentido de pormos fogo onde de fato deve arder a chama. Tal tarefa, que consiste justamente na necessidade de dirigir o processo político que fez irromper as mobilizações, não é possível de se realizar pelos bravos e combativos movimentos espontâneos que já vêm fazendo a sua parte ao incendiar a realidade. A tarefa cabe àqueles que podem ir além de breves e localizados incêndios: os partidos, como forças dirigentes.

No sentido gramsciano, tal capacidade dirigente pressupõe a articulação de um bloco histórico necessário à conquista da hegemonia como predomínio da vontade geral (como interesse universal) sobre as vontades particulares e singulares. Se bem entendida, a vontade geral não pode se resumir a uma simples soma de vontades particulares, mas a predominância dos interesses comuns sobre os interesses privados, tal como a temos no pensamento de Rousseau (COUTINHO, 1994).

Sabemos que Lenin e Gramsci desenvolveram suas ideias a partir de seus mestres maiores: Marx e Engels. No Manifesto do Partido Comunista eles chegaram a uma formulação que já vinham perseguindo no crucial período de 1843 a 1847 segundo a qual a emancipação do proletariado é obra do próprio proletariado. Nesse sentido, a 
revolução surge como revolução da maioria no interesse da imensa maioria, ou, como assinalou o professor Michael Löwy, em conhecido estudo: o processo revolucionário aparece no Manifesto como autoemancipação proletária mediada por organismos coletivos de classe (LÖWY, 2002). Nesse momento, Marx e Engels já distinguiam dentre as organizações políticas aquelas voltadas aos interesses particulares ou aos universais, distinção que já aparecia, de modo explícito, na Miséria da Filosofia, obra anterior ao Manifesto, conforme veremos.

O que Marx e Engels buscaram foi, na verdade, o sentido histórico do processo da revolução ou, como gostava de afirmar o Professor Florestan Fernandes, a determinação do curso da revolução se encontra na história como história em processo (FERNANDES, 1989). Tal sentido histórico descoberto pelos pais do materialismo históricodialético foi por eles revelado em textos anteriores que enfrentaram tradições teóricas tão marcantes na primeira metade do século XIX: a influente economia política clássica, sobretudo a inglesa; a grande filosofia clássica alemã; e as generosas ideias dos socialistas utópicos, principalmente francês e inglês. A história tomada como um processo ininterrupto ou, como dizia Lukács, a história como o jorrar incessante do novo pode ser exemplificada numa passagem, tão bem citada na Conferência do professor Cheisnais, de um livro de Marx e de Engels ( $A$ Sagrada Família) que é parte daquele enfrentamento com o legado teórico do tempo em que viviam: A história não é nada. São os homens que a fazem.

\section{O CAMINHO DE MARX E DE ENGELS PARA DESCOBRIR O "SEGREDO" DAS LUTAS DE CLASSES}

"A história de todas as sociedades até hojeé a história das lutas de classes". Essa aparentemente simples afirmação contida na abertura do capítulo I do Manifesto do Partido Comunista era, no tempo de nossos autores, o avesso (como ainda o é) do pensamento dominante. A novidade consistia justamente em inaugurar uma nova perspectiva teórica - a teoria social da ordem burguesa, que só se tornaria completa nos anos 1860 quando Marx dá forma definitiva à sua crítica da economia política - cujo método de apreensão da realidade tem na categoria de mediação um de seus pilares.

Como nosso intuito é discutir a relação entre as lutas sociais e a questão do mediador universalizante, daremos uma atenção especial a esse segundo ponto, tratando-o como mediação universal histórico-concreta, para depois retornarmos ao que chamamos de sentido histórico das lutas de classes nas obras de Marx e de Engels. Importa agora descobrir como eles chegaram a essa forma de apreender o movimento das classes sociais e como puderam perceber, acima e além de notáveis pensadores de seu tempo, a existência de uma universalidade concreta que nada tinha a ver com as fórmulas, por vezes geniais, que brotavam da cabeça dos filósofos.

Em outras palavras, tal forma de apreensão da história, ou se quisermos, tal método de análise histórica, permitiu que eles superassem, de uma só vez, as correntes filosóficas e teórico-políticas mais influentes da transição do século XVIII para o XIX e da primeira metade dos anos 1800: desde a genialidade de Rousseau - que ainda carecia de elementos de mediação histórico-concretos e trabalhava com uma universalidade ainda pouco determinada - que tanto influenciou a grande Revolução Francesa no final do século XVIII e as mais generosas ideias dos socialistas utópicos franceses das primeiras décadas do século XIX, ao universalismo abstrato, ainda que com reconhecimento dos elementos de mediação das particularidades, de Hegel e do neo- hegelianismo. Foram tais superações dessas modalidades de apreensão do real, e de seus elementos de mediação, como universal-abstrato, que criaram as condições para suplantar também as bases do materialismo sem história (ou sem sujeito histórico) de origem feuerbachiana que tanto influenciou Marx pelo menos até $1844^{3}$.

Para chegar a essa forma de apreensão da história - tão cara ao desenvolvimento de uma teoria da revolução que está na base da relação entre lutas sociais/mediação universal que estamos problematizando - nossos autores atuaram numa luta que não foi apenas teórica. As condições que permitiram a eles aquelas superações surgiram tanto da luta teórica quanto da luta política. Ou, trocando em miúdos: Marx e Engels não inventaram um método novo; eles arrancaram da realidade o seu próprio movimento imanente, revelando por meio do pensamento a sua dinâmica. E só puderam chegar a tal termo porque mergulharam fundo na realidade através de um processo de investigação que determinava um "objeto de estudo" não pelas preferências do pesquisador, mas pela possibilidade de conhecimento - e pela fidelidade ao movimento do real - que um ou outro fenômeno da realidade oferecia enquanto fenômeno concreto rico de determinações a serem desveladas. Tal critério metodológico foi descoberto por Marx na própria realidade, por meio de rigorosos processos investigativos e a partir de momentos de saltos e de rupturas resultantes de suas próprias experiências práticas e políticas, algumas bastante conhecidas de sua trajetória, como, por exemplo, a experiência jornalística no periódico Gazeta Renana entre $1842 / 1843$ ou o impacto que lhe causou o levante dos tecelões da Silésia em junho de 1844.

Esses momentos de saltos e de rupturas compõem o crucial período da trajetória do jovem Marx, entre 1843 e 1847. Já nos Anais Franco- 
alemães do primeiro semestre de 1844, revista projetada por Marx e por seu companheiro Arnold Ruge - um jovem hegeliano de esquerda que jamais superaria os limites de um liberal-progressismo cujo objetivo principal era o de buscar relacionar a filosofia clássica alemã ao pensamento político francês, figuram dois textos que são peças importantíssimas para o caminho das superações que Marx realizou. O primeiro deles, Para a Questão Judaica $\left(1843^{4}\right)$, tem a maior importância no edifício do pensamento marxiano. Pela primeira vez, Marx aponta o limite da emancipação possível na ordem burguesa. Recorde-se de que até então nosso autor não é mais do que um, como o eram tantos dentre os jovens hegelianos de esquerda, democrata radical. Para além de seu então mestre Bruno Bauer, Marx aponta o limite da crítica de Bauer, circunscrita que estava ao problema da religiosidade dos judeus e da alienação dela derivada. Para ele, o problema não está na ausência do direito à liberdade de credo no atrasado (porque ainda preso aos quadrantes da institucionalidade feudal) Estado prussiano e nem na alienação religiosa, seja ela oriunda do judaísmo ou de qualquer outra religião.

Para Marx, a questão central está na impossibilidade de emancipação humana no âmbito da nova ordem burguesa que só faculta aos homens os limites de uma emancipação do tipo política garantida em termos formais pelo Estado. A impossibilidade da emancipação humana se relaciona com a impossibilidade de igualdade econômica real entre os homens. Estes vivem uma dupla condição que os cinde como gênero humano: como membros de uma abstrata comunidade encarnada no Estado são cidadãos; como homens reais, vivem como indivíduos possessivos em meio a relações econômicas desiguais que condicionam sua existência como seres prático-sociais ${ }^{5}$. E foi a descoberta dessa cisão entre indivíduo burguês e cidadão abstrato - no fundo Marx descobriu que os homens viviam uma condição de igualdade formal-jurídica - que permitiu a nosso autor uma maior clareza para enfrentar tanto os limites do liberalismo quanto os impasses do idealismo hegeliano.

O outro texto que comparece no projeto dos Anais chama-se Crítica da Filosofia do Direito de Hegel. Introdução $\left(1843^{6}\right)$, onde se desenvolve a crítica de 1843, primeira crítica do pensamento e da obra de Hegel, que o autor já tematizara naquele ano num manuscrito preparado durante sua breve passagem por Kreusnach (assim conhecido por Manuscrito de Kreusnach ${ }^{7}$ ). Com um conhecimento ainda muito precário da economia política clássica e, por isso, insuficiente da sociedade capitalista, Marx se esmeraria em superar o que considerava um problema central da filosofia de Hegel: o tratamento das contradições reais que já lhe pareciam inconciliáveis como contradições que se resolveriam no Espírito Objetivo, como se fosse uma Ideia Absoluta surgida da cabeça do filósofo. Ou seja, aquilo que em Hegel já aparece como superação de Rousseau (no que diz respeito aos elementos de mediação resultantes dos interesses particulares) e que permite ao filósofo alemão alcançar as contradições do presente, próprias do grau mais complexo do desenvolvimento das relações sociais no capitalismo, ainda muito pouco desenvolvidas no tempo do pensador genebrino, são resolvidas pelo grande filósofo alemão através de um conceito abstrato de Estado que em si superaria idealmente as contradições sociais. Foi por isso que Marx percebeu, a partir e para além de Hegel, que a chave para o conhecimento da realidade da nova sociedade, profundamente revolucionária dos métodos de produção de riqueza social, estava justamente na economia, no modo de funcionamento econômico desta nova ordem societária. Objetivamente, Marx notou que não iria muito longe se nãoconhecesse a anatomia da sociedade civil.

E é também na crítica à filosofia do direito de Hegel que Marx identificará, pela primeira vez - ademais de se identificar, também pela primeira vez, como comunista -, o sujeito histórico da emancipação, o jovem proletariado, ainda que de modo genérico, pouco preciso. Justamente por ainda carecer de um conhecimento mais concreto da ordem burguesa, Marx tem uma noção do proletariado que ainda não é rica de determinações. Não custa lembrar que Marx ainda opera com uma concepção de homem ou, se quisermos, com uma antropologia herdada de Feuerbach, pois que não chegou numa própria apreensão do homem como ser social e que, também, pouco conhece da anatomia da sociedade civil, exigência que já se punha, mas que àquela altura não vai além da sociedade civil ou do conhecimento da vida econômica que toma emprestado, essencialmente, de Hegel. Por isso, o proletariado aparece no texto dos Anais mais como uma classe redentora do que uma classe ontologicamente revolucionária ${ }^{8}$.

Tal limite começa a ser superado no mesmo ano de 1844 quando Marx se pôs a estudar, pela primeira vez de modo sistemático, a ordem burguesa, sua estrutura econômica e morfologia social, no conjunto de manuscritos elaborados em Paris que tematizam de modo inédito, até aqui, a propriedade privada burguesa e as formas de consciência que derivam da divisão social do trabalho capitalista, deslocando a centralidade da alienação religiosa presente em Feuerbach para a alienação social condicionada pela propriedade privada dos meios de produção. Por isso, nos Manuscritos Econômicofilosóficos de 1844 temos, simultaneamente, uma primeira apreensão crítico-sistemática de Marx da economia política bem como um afastamento, que se desdobraria em superação, das ideias feuerbachianas.

Dissemos alguns parágrafos acima que a 
luta teórica não se deu separada da luta política na trajetória de Marx. Na ocasião, lembramos a revolta dos operários tecelões da Silésia, parte do edifício da Confederação Germânica do reino da Prússia, situada no lado oriental da Prússia. Pois bem, tal fato teve um impacto muito significativo para o pensamento de Marx. Em agosto de 1844 ele escreveria um valioso texto de crítica a um artigo de seu companheiro A. Ruge que fez uma análise ainda presa aos limites de seu liberal-progressismo. O texto marxiano, publicado com um título pouco atraente - Glosas críticas ao artigo O rei da Prússia e a reforma social: de um prussiano -, apresenta mais que uma crítica a Ruge. Marx percebe que a insurgência dos silesianos era a prova real que precisava para mostrar na prática a existência de aspectos centrais da sociedade capitalista que vinha notando e estudando desde suas experiências jornalísticas na Gazeta Renana, quando se deparou com as duras condições de vida e de trabalho dos lenhadores criminalizados na Renânia e dos vinhateiros da região da Mosela.

Se, àquela altura de seu trabalho no periódico renano (entre março de 1842 e janeiro de 1843), Marx apenas mantinha uma postura democrática e humanista que o levou a condenar a situação social de exploração e criminalização dos trabalhadores, em 1844 ele já reunia armas teóricas suficientes não só para denunciar a injustiça a que foram submetidos os revoltosos tecelões, duramente reprimidos pelas forças armadas prussianas. O levante de junho de 1844 fez saltar aos olhos de Marx o sentido concreto da revolução social que, para além do que pensavam e idealizavam os filósofos, se apresentava como uma necessidade histórica do proletariado que a afirmava na prática política concreta como seu projeto de emancipação. Ao mesmo tempo, Marx via na ação política do proletariado insurgente a materialização do sujeito histórico da revolução que se afirma como tal através de lutas políticas concretas que objetivam a realização prática da necessidade histórica da emancipação.

As Glosas críticas indicam uma descoberta que Marx aprofundaria nos textos subsequentes até chegar à categoria de práxis, já antes tematizada pelo comunista filosófico Moses Hess, e que apareceria posteriormente nas famosas Teses sobre Feuerbach ${ }^{9}$, publicadas em 1926. Para tanto, realiza, com Engels, projeto que estabelecem já em 1844, quando se conhecem, um amplo balanço crítico do neo-hegelianismo no livro, publicado em fins de fevereiro de 1845, com o título de A Sagrada Família. Crítica da crítica. Contra Bruno Bauer e consortes - um ácido e fundamentado estudo crítico dos limites do neoidealismo alemão do qual não se livraram os jovens hegelianos que, organizados em torno do grupo Livres de Berlim, encontravam-se cada vez mais presos a uma postura meramente teórica, despolitizada e apartada da realidade.

Nossos autores avançariam na crítica ao idealismo no monumental e clássico $A$ Ideologia Alemã, no qual lançam as bases para a fundação do materialismo histórico- dialético. No famoso texto de 1845-1846 Marx e Engels diriam, numa formulação depois recuperada pelo primeiro n' 018 Brumário de Luis Bonaparte, que os homens são capazes de fazer a história, mas a partir de condições legadas pelo passado que determinam o curso dos acontecimentos. Aqui, como já comparecia, tendencialmente, nos Manuscritos de 1844, a dialética é posta no chão concreto da vida material. Não é a consciência que determina a existência, mas esta é que produz formas específicas de pensamento de acordo com o momento histórico que condiciona a vida dos homens. Por meio de um processo de objetivação e de subjetivação, os homens realizam seus objetivos e se subjetivam através da atividade prática que tem no trabalho sua base primária pelo qual os homens produzem riqueza material. Através do trabalho, da práxis produtiva, estrutura-se um conjunto de outras atividades como modalidade de práxis existentes em função do ato primário do trabalho. Nesse sentido, os homens são produtos de sua autoatividade. São, assim, seres práticos e sociais na medida em que organizam materialmente a sua vida material a partir das condições históricas objetivas com as quais se deparam.

Entre 1845 e 1848 Marx e Engels estreitaram suas relações com o movimento operário de tal forma que jamais se desligaram dele. Desse período conta-se a aproximação com o movimento cartista (que Engels já conhecia), a experiência, a partir da Bélgica onde Marx se encontrava desterrado, do CCC (Comitê de Correspondência dos Comunistas), a participação nas atividades da Sociedade Operária dos Emigrados Alemães sediada em Paris e, sobretudo, a aproximação à Liga dos Justos. Ademais da intensa atividade política do período, especialmente durante o fecundo exílio belga, Marx não deixa de prosseguir seus estudos, apropriandose de assuntos os mais diversos e aprofundando seus conhecimentos sobre a economia política.

No mesmo período, provocado pelo impacto que a leitura do novo livro de Proudhon ( $A$ Filosofia da Miséria, saído no segundo semestre de 1846) Ihe causou, Marx escreve uma dura crítica às ideias do autor - que tanto influenciava o incipiente movimento operário, especialmente o francês - que acabaram resultando num livro Miséria da Filosofia, publicado no início de 1847 - que vai muito além do rechaço ao problemático pensamento de Proudhon. Nele os avanços marxianos anteriores aparecem articulados a um maior domínio da economia política, o que levou Ernest Mandel a considerar a obra como um primeiro esboço da crítica da economia política, ou como diria o marxista belga: a "[...] primeira obra econômica de Marx". (MANDEL, 1968). O método de análise histórica se volta para a crítica dos equívocos proudhonianos e o resultado é que 
Marx acaba avançando na sua teoria da revolução em dois pontos fundamentais: o primeiro deles apresenta uma perspectiva que trata a revolução como um processo essencialmente prático. A práxis revolucionária é expressão das lutas concretas que se estabelecem em níveis diferenciados de evolução: das reações espontâneas defensivas do proletariado aos protestos operários e destes às coalizões que vão se formando à medida que avança, na prática política concreta, a consciência de classe dos trabalhadores. Dos níveis embrionários de lutas (de uma existência de classe em si) os trabalhadores saltam para graus mais desenvolvidos de consciência até atingirem, através de organismos políticos mais amplos e universais (que Marx identificava então no movimento cartista), uma forma de consciência de classe-para-si. Na Miséria da Filosofia encontramos pela primeira vez, de modo mais acabado, a necessidade da construção de instrumentos políticos de mediação. Esses organismos políticos de classe são tão mais desenvolvidos quanto mais capacidades reúnem para alcançar a universalidade concreta que envolve e determina a vida dos trabalhadores numa só condição de classe. O antagonismo central da sociedade capitalista entre capital e trabalho exige que se ergam mediadores das diversas demandas (de classe) que se apresentam na superficialidade dos fenômenos como demandas isoladas.

3 CLASSES E LUTAS DE CLASSES: do Manifesto às análises das revoluções de 1848-1849

Mas voltemos ao Manifesto para em seguida retornarmos ao problema que estamos tratando neste artigo. Dentre tantos avanços teóricos do clássico de 1848, dois deles devem ser destacados aqui.

O primeiro se refere à afirmação da perspectiva de revolução que, se já comparecia em textos anteriores, surge no Manifesto articulada a uma análise global da ordem burguesa. $O$ sentido da revolução é aquele que articula conhecimento teórico da realidade com ação política consciente. A autoemancipação do proletariado pressupõe uma tomada de consciência de classe possível se ela for capaz de compreender-se a si mesma a partir das experiências concretas das lutas de classes e se, a partir disso, conseguir reunir seus interesses comuns em organismos políticos próprios. A revolução aparece então como uma necessidade histórica que se coloca, na verdade, como uma possibilidade histórica, pois que depende da vontade política consciente (daí o pressuposto do conhecimento teórico) e organizada (que pressupõe instrumentos políticos de mediação dos interesses de classe) do proletariado.

O segundo avanço teórico que deve ser notado aqui diz respeito à presença no texto de uma análise global da sociedade burguesa que desborda aquela que está presente na Miséria da Filosofia. O texto de 1848 traz muito mais que uma análise do período histórico em que surgiu, uma vez que aponta tendências do potencial desenvolvimento capitalista que seriam conhecidas no futuro. Ainda que tenhamos elementos problemáticos nos prognósticos de Marx e de Engels, pontuados abaixo, não há dúvidas de que estamos diante de uma análise que, em muitos de seus aspectos, resistiu e resiste ao tempo.

Muitos analistas tendem a identificar no clássico texto de 1848 uma tendência de reduzir as lutas de classes à polarização entre burguesia e proletariado. Essas análises podem ser levadas em consideração desde que relacionadas a três aspectos importantes, um de natureza histórica e dois de natureza teórico-metodológica.

O de natureza histórica diz respeito à época que Marx e Engels tinham como matéria-prima, quando a classe operária praticamente se resumia à indústria têxtil e à mineração, setores produtivos que se encontravam mais ou menos desenvolvidos em alguns países europeus, destacadamente Inglaterra, Bélgica e, em menor grau, França e Alemanha. Tal constatação em nada diminui os resultados obtidos no texto. Ao contrário: como veremos a seguir, mesmo diante de uma realidade ainda não plenamente desenvolvida do ponto de vista das relações capitalistas, nossos autores foram capazes de ultrapassá-la. E assim o fizeram sem conceder a ilusões de retrocesso ao passado e sem soluções fantásticas ou fantasiosas tão comuns entre os utópicos do socialismo que agiam mesmo como idealistas reformadores do mundo.

O segundo aspecto, teórico-metodológico, refere-se ao esforço dos autores em identificar a contradição central dentre tantas contradições sociais que envolviam diversas camadas de classes, desde as remanescentes da velha ordem feudal até aquelas novas, emanadas da nova sociedade burguesa, que ainda estavam em formação. Eis aqui um dos maiores méritos do texto clássico que reside, justamente, nessa identificação que arrancou da realidade aquilo que ainda era germe. E é importante recordar que o principal objetivo do texto teórico-político era o de apresentar o programa da recém- constituída Liga dos Comunistas. Assim, - Manifesto foi também uma tentativa de acertar na análise da realidade concreta para criar condições para acertar na ação política.

O terceiro aspecto, também de natureza teórico-metodológica, talvez seja aquele que mais atribui ao texto a qualidade de um clássico que transcende seu tempo: o que parece simplificação para alguns (a redução das lutas de classes à polarização entre burguesia e proletariado) constituía-se, em verdade, numa magistral análise que desbordava largamente o tempo histórico em que surgiu. $O$ que para alguns é simplificação, na 
verdade é uma projeção tendencial ${ }^{10}$, para além dos limites históricos da época, que indicava o desenvolvimento contraditório das relações capitalistas. Tal projeção tendencial se inscreve, precisamente, na identificação do movimento essencialmente contraditório do desenvolvimento capitalista (a expansão capitalista - como expansão da produção da riqueza social excedente - é expansão da exploração dos trabalhadores), análise inédita que é parte da revolução teórica da teoria social marxiana. A simplificação é, então, a identificação do antagonismo central entre capital e trabalho que traz em si também o embrião daquilo que Marx chamaria n' O Capital de lei geral da acumulação capitalista que aprofunda aquela descoberta corrigindo alguns aspectos que aparecem problemáticos em 1848. O amplo desenvolvimento da sociedade capitalista até nossos dias, que tanto modificou o perfil das classes sociais, em nada modificou aquele antagonismo central. Bem ao contrário, ele se tornou mais profundo e complexo e, por isso mesmo, de difícil identificação de suas expressões concretas e particulares, o que exige enorme esforço de atualização no sentido de localizar, nas formas atuais das classes e das lutas de classes, a sua prevalência.

Entretanto, é verdade que em textos posteriores Marx e Engels tenham esboçado maior riqueza analítica das classes e das formas de lutas entre elas. No conjunto de textos que envolveram os acontecimentos que abalaram a Europa entre 1848 e 1851 Vemos que a polarização entre burguesia e proletariado aparece articulada a uma gama de sujeitos coletivos intervenientes nos processos políticos da época. Isto pode ser visto já nas ideias elaboradas no calor dos acontecimentos, presentes em mensagens políticas publicadas no periódico Nova Gazeta Renana, periódico que funcionou mesmo como órgão da democracia. Ou antes mesmo dos textos que saíram no periódico, deve-se destacar o programa político da Liga dos Comunistas - Reivindicações do Partido Comunista na Alemanha ${ }^{11}$ - que nossos autores preparam no momento mesmo em que explodem processos revolucionários naquele país, em março de 1848. Porém, é do período pós-revoluções de 1848-1849 que brotaram análises das experiências que aprofundam os elementos que nos interessam aqui.

Na Mensagem do Comitê Central à Liga, de março de 1850, Marx e Engels, com o intuito de reerguer a Liga dos Comunistas que se encontrava derrotada e em luta interna fratricida, acabaram por nos deixar contribuições que superam em muito aquele objetivo que era o de tentar salvar a organização que seria definitivamente extinta em 1852. O problema das alianças de classes, tão caro ao movimento operário no curso das revoluções, reacendeu a questão da defesa da autonomia de classe como princípio intransigente.
A traição da burguesia, especialmente aquela que se viu na Alemanha e que frustrou as expectativas revolucionárias, colocou na ordem do dia a necessidade de o proletariado articular formas radicalmente autônomas que permitissem a realização de alianças sem prejuízo de perda dos objetivos dos trabalhadores. Daí a necessidade de se constituir um duplo poder que deveria se organizar a partir da criação de meios e instrumentos próprios para o exercício da democracia proletária. Tais meios não impediriam que a luta política se desenvolvesse nos espaços existentes na ordem burguesa, mas dotariam o proletariado de capacidade de preservar seus objetivos e de enfrentar com maior força política o poder das classes dominantes. Essa dualidade de poderes supõe a construção ou o fortalecimento de aparelhos políticos próprios, tais como: clubes operários, centros de formação, instrumentos de propaganda política e ideológica, órgãos associativos diversos e, também, meios armados. A Mensagem de 1850, no fundo, discute a questão da estratégia da revolução, especificamente a necessidade de distinguir os momentos que separam os processos que conduzem à revolução democrática e à revolução social, ou, para sermos mais precisos, da revolução democrática à revolução social. Daí que surge a expressão revolução permanente como forma de expressar, ao mesmo tempo, a funcionalidade (e os limites) da revolução democrática como emancipação política e o horizonte da revolução social como emancipação humana.

A mesma riqueza analítica aparece em nível mais profundo nos textos que compõem As lutas de classes na França, 1848-1850 (conjunto de três textos de Marx e um de Engels publicados em $1895^{12}$ ) e nos oito capítulos de O 18 Brumário de Luis Bonaparte, obra-prima de Marx publicada em 1852 que analisa os acontecimentos que provocaram o golpe desferido pelo sobrinho de Napoleão em dezembro de 1851. Nestes livros despontam magistrais análises de conjuntura que trazem um rico quadro das inúmeras classes sociais em presença, seus interesses políticos e econômicos, as formas políticas de dominação condensadas no Estado até a constituição do fenômeno bonapartista, destacando sempre o papel desempenhado pela burguesia e pelo proletariado em seus diversos estratos.

\section{AS MUTAÇÕES HISTÓRICAS DO CAPITALISMO, AS LUTAS SOCIAIS E A QUESTÃO DA MEDIAÇÃO UNIVERSAL}

Em muitos aspectos o capitalismo atual difere daquele que Marx e Engels puderam conhecer. A incrível atualidade de suas ideias se deve à imensa capacidade que tiveram de antecipar tendências que seriam conhecidas pelas gerações posteriores, inclusive a nossa. Alguns desses aspectos merecem 
ser destacados (e não faremos mais que destacá$\left.10 s^{13}\right)$, precisamente quatro mais importantes, para pensarmos como se apresentam em nossos dias e como eles se relacionam com o presente quadro das lutas de classes.

O primeiro se refere ao problema da identificação do sujeito histórico da revolução. Já no tempo de Marx e de Engels a grande indústria capitalista havia se desenvolvido extraordinariamente. Em um dos capítulos do Livro I d' O Capital (precisamente o capítulo XIII), Marx demonstra a enorme capacidade produtiva da moderna indústria capitalista garantida pelos formidáveis progressos técnico-científicos e tecnológicos.

$O$ segundo aspecto diz respeito às formas atuais de extração da mais-valia. Se no tempo de Marx já se podia notar que a prevalência da forma absoluta dava lugar, com o incremento tecnológico, à forma relativa, no capitalismo contemporâneo percebe-se uma maior tendência de combinação das duas formas, inclusive nos países mais desenvolvidos. A tendência de precarização do trabalho criou um amplo segmento de trabalhadores que vivem em condições bastante adversas, marcadas por vínculos temporários, parciais e instáveis. Esse amplo estrato de trabalho precário - maior ou menor, a depender do grau de adesão dos países às políticas neoliberais hegemônicas no mundo burguês - compõe parte considerável do exército industrial de reserva contemporâneo, precisamente a sua camada flutuante. Isso significa que o movimento sindical tende a seguir uma postura mais recuada e está mais sujeito a ser cooptado, justamente por se encontrar diante de uma realidade que coloca os trabalhadores na defensiva porque os divide e fragmenta, dificultando a construção da identidade de classe.

Um terceiro aspecto que envolve o quadro atual das lutas de classes tem a ver com o grau acentuado de desenvolvimento do capitalismo monopolista que agudiza a tendência de centralização de capitais aumentando o poder do capital financeiro sobre os países que vivem sob o domínio do sistema econômico imperialista. Tal processo de centralização, que significa um maior comando do capital monopolista sobre os Estados e governos, tende a exercer um forte controle do aparato estatal que é inteiramente colocado a serviço da oligarquia financeira que estabelece zonas de influência econômica e de partilha do mundo. É mais que atual a análise que Lênin realizou do imperialismo ${ }^{14}$ que prognosticava a formação, sincronicamente ao sistema econômico imperialista, de um sistema político do imperialismo que submete as nações periféricas ou semiperiféricas ao poderio econômico e bélico das nações dominantes. O resultado é bem sintetizado por Atílio Borón (2010): segundo o marxista argentino, ao mesmo tempo em que a classe trabalhadora se complexificou e se tornou mais heterogênea, a burguesia condensou seus interesses nos monopólios, homogeneizando-se enquanto classe.

Um quarto e último aspecto que destacaria diz respeito a um efeito contraditório do desenvolvimento capitalista contemporâneo. Aquela tendência de combinação da mais- valia absoluta com a maisvalia relativa produz uma forma combinada de pauperização. Mesmo que se considere o maior ou menor predomínio de políticas neoliberais e o grau de introdução de inovações tecnológicas nos diversos países (centrais e periféricos), observa-se uma tendência que combina pauperismo absoluto - quando os trabalhadores experimentam níveis acentuados de exploração do trabalho e formas acentuadas de degradação das suas condições sociais - com pauperismo relativo - quando, mesmo que não vivam sob condições aviltadas de vida, os trabalhadores produzem com mais intensidade e aumentam a produção da riqueza social excedente deles expropriada. Nessas condições, eles podem até perceber relativas melhoras em sua vida - efeito do desenvolvimento contraditório capitalista que pode até mesmo elevar os níveis de consumo de mercadorias, como se vê em diversas regiões do mundo - mas, por outro lado, o excedente econômico que produzem torna-se mais se concentrado nas mãos dos capitalistas.

Também por efeito das contradições capitalistas, mesmo aqueles que vivem sob formas de pauperização absoluta são alvos de políticas assistenciais e compensatórios que, aplicadas por diversos governos em todas as regiões do mundo, visam justamente os mais pobres e atuam para atenuar os antagonismos de classe que, ainda que se encontrem acentuados, permanecem relativamente controlados. Paralelamente às funções coesivas adotadas, crescem também as formas repressivas do aparelho estatal armado cada vez mais eficazes, seja para encarcerar boa parte da população sobrante, para criminalizar movimentos sociais ou, simplesmente, para promover o puro extermínio dos segmentos mais empobrecidos viventes nas periferias dos grandes centros urbanos capitalistas. O resultado é o seguinte: parte das massas trabalhadoras se conforma com o consumismo; outra parte é objeto das políticas sociais minimalistas do Estado capitalista; uma outra sofre a mão pesada da repressão estatal. Diante de tal quadro, é bastante adversa a situação do proletariado na cena contemporânea das lutas de classes, como também o é pensar a questão da mediação universal.

\section{TUDO QUE É SÓLIDO DESMANCHA NO AR}

Este quadro adverso que traçamos recordemos:aexpansão do trabalhosocialcombinado 
ou do trabalhador coletivo da grande indústria que fragmenta e divide a classe trabalhadora e dificulta a identificação do sujeito revolucionário; a tendência de combinação da mais-absoluta (que avilta a vida do trabalhador) com a mais-valia relativa (que, dentre outras consequências, eleva o contingente do exército industrial de reserva, especificamente a sua camada flutuante); a também combinação de pauperismo absoluto (alvo das políticas de controle da pobreza) com o relativo (que eleva o consumo, mas aumenta a apropriação privada da riqueza social excedente); e a homogeneização dos interesses capitalistas condensados nos grandes grupos monopolistas em detrimento da maior heterogeneização dos interesses sociais da classe trabalhadora -, todo esse quadro parece ser instransponível.

Mas tudo que é sólido desmancha no ar. E a aparente solidez desse quadro pode a qualquer momento se dissolver, como de fato começou a se dissolver, por exemplo, em junho de 2014, no Brasil.

É evidente que a questão da mediação universal se complexificou com o desenvolvimento do capitalismo. Incontáveis modificações atribuíram àquela questão a necessidade de novas formas de organização política que deem conta tanto das múltiplas particularidades que caracterizam o capitalismo contemporâneo quanto de pensálas no âmbito de uma universalidade concreta que as abranja. Nesse sentido, tem razão José Paulo Netto (2012) quando identifica o que chamou de déficit organizacional no campo da esquerda contemporânea. A constatação do autor se relaciona mais a aspectos qualitativos que quantitativos, uma vez que o problema não está na falta de organismos políticos que na atualidade são incontáveis, mas à capacidade (ou a incapacidade) que eles reúnem para adotar formas políticas de ação mais sintonizadas com as demandas sociais sobre as quais atuam.

Tal dificuldade (e, talvez, seja esse o problema que Netto queira realçar) recai mais fortemente sobre as organizações tradicionais da esquerda, cujos modelos de atuação e de mobilização remontam às formas clássicas que conhecemos, especificamente ao movimento sindical e ao partido revolucionário. Se compararmos o tempo histórico de Marx e Engels, de Lênin e até mesmo de Gramsci ao nosso século XXI, certamente não restará dúvidas de que devemos repensar as estruturas que moldaram aqueles organismos clássicos, buscando atualizar suas formas de atuação e manter os elementos que permitiram avanços e conquistas da classe trabalhadora ao longo dos séculos XIX e XX.

Porém, também não há dúvidas de que parte da esquerda contemporânea que vem renovando suas formas de atuação tem se pautado em fórmulas teóricas que em nada atualizam os clássicos da tradição marxista que vêm sendo, em verdade, abandonados pelas correntes teóricas hegemonizadas seja pelas ideias pós-modernas, seja pelas ideias anarquizantes de uma certa esquerda radical. Apresentam o reino do particularismo, encantam-se com todo tipo de espontaneísmo, vendem o universalismo abstrato da multidão e acreditam apenas nas formas de democracia direta, sem mediações, onde cada indivíduo (ou grupo) representa-se a si mesmo. Sonham com uma polis grega em pleno capitalismo do século XXI, como se o proletariado fosse um cidadão livre pronto para atuar na ágora capitalista! Nesse sentido sustentam ideias que podem ser consideradas pré ou antimodernas, pois que estão ancoradas em pressupostos que descartam o movimento histórico como totalidade concreta que pode, pela razão, ser reproduzido idealmente. Tais ideias são estranhas até mesmo a Rousseau que, como vimos, viveu uma época em que o capitalismo pouco havia se desenvolvido, e para quem a democracia encarnada na soberania popular advém do predomínio da vontade geral sobre as vontades individuais, ainda que sem elementos de mediação, mas já longe do triunfo do indivíduo possessivo do liberalismo. Para além dele, foi Hegel e depois Marx que exploraram e resolveram o problema da relação entre os interesses particulares e os interesses universais - o primeiro por meio de uma dialética idealista e o segundo através de uma dialética materialista. E é exatamente tal resolução teóricofilosófica que está sendo abandonada, justamente numa época em que ela é mais do que necessária. E é precisamente ela que a esquerda deve preservar e atualizar como forma de pensar estratégias de organização próprias aos nossos tempos. E é por isso que optamos nesse breve texto por recuperar esse debate tão caro para o futuro da humanidade.

\section{REFERÊNCIAS}

BARATA-MOURA, J. Estudos sobre a ontologia de Hegel: ser, verdade, contradição. Lisboa:Avante, 2010.

BORÓN, A. O socialismo no século XXI: Há vida após o neoliberalismo? São Paulo: Expressão Popular, 2010.

BOTTIGELLI, E. A gênese do socialismo científico. Lisboa: Editorial Estampa, 1971.

BRAZ, M. Apresentação a "Que fazer?". In: LENIN, V. I. Que fazer?: problemas candentedo nosso movimento. São Paulo: Expressão Popular, 2010. p. 9-38.

Partido e Revolução 1848-1989. São Paulo: Expressão Popular, 2011.

CLAUDÍN, F. Marx, Engels y la revolución de 1848. Madrid: Siglo Veintiuno Editores, 1975. 
COUTINHO, C. N. Marxismo e política: a dualidade de poderes e outros ensaios. São Paulo: Cortez, 1994.

FERNANDES, F. Introdução: Marx-Engels, História. São Paulo: Ática, 1989. (Coleção Grandes Cientistas Sociais).

FREDERICO, C. O Jovem Marx - 1843-1844: as origens da ontologia do ser social. 2. ed. São Paulo: Expressão Popular, 2009.

LENIN, V. I. Que fazer?: problemas candentes do nosso movimento. Tradução de M. Braz. São Paulo: Expressão Popular, 2010.

LÖWY, M. A teoria da revolução no Jovem Marx. Petrópolis, RJ: Vozes, 2002.

MCLELLAN, D. Karl Marx, vida e pensamento. Petrópolis, RJ: Vozes, 1990.

MANDEL, E. A formação do pensamento econômico de Karl Marx: de 1843 até a redação de 'O Capital'. Rio de Janeiro: Zahar, 1968.

MARX, K. A Sagrada Família. São Paulo: Boitempo, 2003.

\section{NOTAS}

1 O texto foi desenvolvido com base na palestra que proferi na VI JOINPP - Jornada Internacional de Políticas Públicas, realizada em agosto de 2013 em São Luis - MA. Optei por preservar o essencial da minha intervenção adequando-a as exigências da linguagem escrita.

2 A história transmitida por escrito, como observou Engels na nota que preparou para a edição inglesa do Manifesto, em 1888.

3 Para uma breve recuperação da trajetória intelectual e política de Marx, tomarei por base as indicações de Barata-Moura (2010), Bottigelli (1971), Braz (2011), Claudín (1975), Frederico (2009), Löwy (2002), McLellan (1990), Mandel (1968), Mehring (2013) e Netto (2012)

$4 \quad$ Publicado em 1844, nos Anais Franco-alemães

5 Note-se que Marx não tem ainda aqui uma clara noção do homem como ser prático-social determinado essencialmente pelas possibilidades concretas que condicionam sua existência. Ainda que já tivesse pistas e que já estivesse na trilha para tal concepção, Marx ainda opera com base numa antropologia feuerbachiana cujos elementos de superação aparecem mais fortemente a partir dos Manuscritos Econômico-Filosóficos de 1844 quando surgem as bases de uma ontologia do ser social marxiana. Ver Frederico (2009).
$6 \quad$ Publicado em 1844, nos Anais Franco-alemães.

7 Neste volumoso manuscrito, Marx já rompe com a ideia de Estado como instituição racional e dá curso aos seus estudos sobre Rousseau e sobre os historiadores da Revolução Francesa (Ludwig, Ranke, Wachsmuth)

8 O Lukács de História e Consciência de Classe, ainda fortemente influenciado por Hegel e que ainda não conhecia as obras que marcariam a ruptura de Marx com a dialética idealista hegeliana, apresenta uma noção do proletariado - em certa medida, voluntarista e, por isso, a-histórica - que a concebe como uma classe redentora. Recorde-se que, se a Crítica da Filosofia do Direito de Hegel. Introduçãofora publicada nos Anais em 1844, as ideias seminais de Marx presentes nos Manuscritos de 1844 e n' A Ideologia Alemã (com Engels) só vieram a público em 1932. O clássico estudo lukacsiano citado na abertura dessa nota de rodapé é de 1926.

$9 \quad$ Publicadas em 1926.

10 Caráter tendencial que não comparece em todas as análises do Manifesto. Por exemplo, os autores ainda carecem de um conhecimento mais profundo e apurado da sociedade capitalista (que, aliás, não aleatoriamente, é designada no texto quase sempre como ordem ou sociedade burguesa) o que não os permitia identificar, como observou, dentre outros, José Paulo Netto, o caráter expansivo do modo de produção capitalista, levando-os a um prognóstico de esgotamento do desenvolvimento das forças produtivas sob relações de produção burguesas num curto tempo histórico.

11 Segundo Michael Löwy (2010), o primeiro programa revolucionário feito durante o momento mesmo da revolução.

12 Os textos de Marx, recolhidos dos artigos que saíram no periódico Nova Gazeta Renana. Órgão da democracia, foram publicados em 1850 com o título 1848 a 1849. Para a edição organizada em 1895, intitulada As lutas de classes na França, Engels acresceu um quarto capítulo e escreveu uma célebre Introdução (prefácio) que ficou conhecida como uma espécie de testamento político engelsiano.

13 Em outros textos busquei aprofundar esses aspectos. Ver Braz (2011b)

14 No clássico Imperialismo. Fase superior do capitalismo. Ensaio popular. Há várias edições publicadas no Brasil. Dentre as mais recentes, vejase a que saiu sob a chancela da editora Expressão Popular.

\section{Marcelo Braz Moraes dos Reis}

Assistente Social

Doutor em Serviço Social pela Universidade Federal do Rio de Janeiro (UFRJ)

Professor da Universidade Federal do Rio de Janeiro (UFRJ)

Professor da Escola Nacional Florestan Fernandes (ENFF) E-mail: reis.braz@ig.com.br 
Universidade Federal do Rio de Janeiro - UFRJ

Avenida Pasteur, 250 Fundos - Botafogo, 22290-240 - Rio

de Janeiro, RJ - Brasil

Escola Nacional Florestan Fernandes - ENFF

R. José Francisco Rapozo, 1140, Guararema - SP 